\title{
PENGARUH PARTISIPASI PUBLIK, TRANSPARANSI ANGGARAN DAN KOMITMEN PERUMUS KEBIJAKAN TERHADAP RESPONSIVITAS ANGGARAN
}

\author{
Benny Sigiro \\ Universitas Terbuka \\ e-Mail: bennys@ut.ac.id
}

\begin{abstract}
This study aimed to investigate the linkages the responsiveness of the budget with public participation, budget transparency and commitment of policy makers in term of local budgeting process. Based on the survey method, data for this study obtained through questionnaires submitted to the respondents include of local governments elements, legislators and public element (citizen, community leaders, NGOs, community organization and other relevant organizations) in Sleman Regency. The data were analyzed to test the hypothesis by using multiple regression analysis. The results of this research showed that public participation, budget transparency and commitment of policy makers, simultaneously and partially has a positive and significant impact on the responsiveness of the budget. The results also confirm the implications and limitations which discussed in the end of the study.
\end{abstract}

Keywords: commitment of policy makers, local budgets, public participation, transparency

\begin{abstract}
ABSTRAK
Penelitian ini bertujuan untuk mengetahui keterkaitan respon dari anggaran dengan partisipasi masyarakat, transparansi anggaran dan komitmen dari pembuat kebijakan dalam hal proses penganggaran daerah. Berdasarkan metode survei, data untuk penelitian ini diperoleh melalui kuesioner yang diajukan kepada responden meliputi pemerintah daerah elemen, legislator dan elemen masyarakat (warga negara, tokoh masyarakat, LSM, organisasi masyarakat dan organisasi terkait lainnya) di Kabupaten Sleman. Data dianalisis untuk menguji hipotesis dengan menggunakan analisis regresi berganda. Hasil penelitian ini menunjukkan bahwa partisipasi publik, transparansi anggaran dan komitmen dari pembuat kebijakan, secara simultan dan parsial memiliki dampak positif dan signifikan terhadap respon dari anggaran. Hasil ini juga mengkonfirmasi implikasi dan keterbatasan yang dibahas dalam akhir penelitian.
\end{abstract}

Kata kunci: anggaran daerah, komitmen pembuat kebijakan, partisipasi masyarakat, transparansi

Reponsivitas menjadi isu penting bagi pemerintah dan institusinya (lihat misalnya, Yang, 2007; Bryer dan Cooper, 2007; Yang dan Pandey, 2007). Pada aras lokal, responsivitas pemerintah daerah semakin menemukan relevansinya ditengah arus desentralisasi dan demokratisasi. Relevansi tersebut berkaitan dengan kewenangan dan keleluasaan pemerintah daerah untuk mengelola Anggaran Pendapatan dan Belanja Daerah (APBD) yang berorientasi pada kepentingan publik. 
Sebagai sebuah kebijakan, anggaran berkaitan langsung dengan alokasi untuk membiayai berbagai program pembangunan dan pelayanan publik dalam rangka pemenuhan kepentingan dan kebutuhan publik. Dengan kata lain, kebijakan anggaran daerah/APBD yang responsif sebagai bentuk manifestasi responsivitas pemerintah daerah kepada publik (masyarakat). Dalam prakteknya, persoalan anggaran ditandai dengan alokasi anggaran untuk belanja rutin pemerintahan dan belanja publik (belanja tidak langsung dan belanja langsung) yang nyaris sulit seimbang. Hal ini tidak lepas dari kenyataan bahwa proses penganggaran sangat terkait dengan proses politik (Wildavsky, 1961), dan oleh karenanya, kebijakan anggaran yang responsif dan efisien tidak serta-merta dapat dilakukan dengan mudah (Hardojo, dkk, 2008).

Secara empiris, anggaran Kabupaten (Kab) Sleman tahun 2010-2013, mayoritas digunakan untuk belanja tidak langsung (BTL) dengan rata-rata mencapai 65,61\% terhadap APBD, dan sisanya $34,39 \%$ merupakan belanja langsung $(\mathrm{BL})$ atau belanja yang berkaitan langsung dengan belanja publik. Dari total belanja tersebut, sebagian besar anggaran $(63,64 \%)$ dialokasikan pada pos belanja pegawai (BL dan BTL). Dalam pelayanan dasar publik, seperti halnya layanan pendidikan yang salah satunya merefleksikan kepentingan masyarakat luas, anggaran pendidikan Kab. Sleman (2010-2013) mencapai 48,23\% atau hampir mencapai setengahnya dari belanja APBD. Namun, dari anggaran tersebut anggaran BL hanya sebesar $16,74 \%$, dan selebihnya $83,26 \%$ merupakan anggaran BTL atau belanja yang tidak dapat dinikmati secara langsung oleh masyarakat pada umumnya. Artinya, jika rata-rata anggaran $\mathrm{BL}$ urusan pendidikan dibagi dengan BL APBD diperoleh prosentase sebesar 24,68\%. Jika melihat pada anggaran BL pendidikan di Dinas Pendidikan tahun 2013 misalnya, hanya sebesar 23,92\% anggaran BL dan bahkan anggaran tersebut lebih banyak digunakan untuk belanja barang dan jasa $(38,54 \%)$, disusul belanja modal $(30,22 \%)$ dan belanja pegawai $(31,24 \%)$.

Kondisi tersebut berfungsi sebagai gambaran bahwa anggaran cenderung digunakan untuk belanja birokrasi dari pada untuk kepentingan publik. Padahal, responsivitas anggaran mensaratkan keberpihakan atau daya tanggap pemerintah daerah terhadap kepentingan dan kebutuhan masyarakat (Hardojo, dkk, 2008). Hal ini berarti permasalahan di dalam memastikan kebijakan anggaran yang responsif, tidak hanya sekadar menyangkut persoalan keterbatasan anggaran daerah. Kecuali itu, studi yang dilakukan oleh Hanida (2010) menemukan bahwa proses penyusunan kebijakan APBD di Kab. Sleman menjadi arena kontestasi kepentingan politik diantara aktor perumus kebijakan anggaran dari kedua lembaga kunci, yaitu pemerintah daerah dan DPRD (eksekutif dan legislatif). Pada konteks itu, penerapan prinsip-prinsip dasar tata kelola yang baik, khususnya partisipasi dan transparansi menjadi agenda penting di tengah arus reformasi anggaran daerah. Muaranya, diharapkan kebijakan anggaran daerah sesuai dengan aspirasi, kepentingan dan kebutuhan masyarakat (Mardiasmo, 2004)

Topik responsivitas menarik untuk didiskusikan. Sejauh ini, studi tentang responsivitas sudah cukup banyak dilakukan dengan beragam fokus penelitian dan telah mengidentifikasi beberapa faktor penting di dalamnya. Namun demikian, tampaknya belum ada studi yang mengkaji hal tersebut terkait dengan responsivitas pemerintah dalam bentuk kebijakan anggaran daerah. Yang dan Callahan (2007) dan Korolev (2012) meyakini partisipasi masyarakat sebagai faktor yang mendorong responsivitas. Sejumlah literatur tentang penganggaran partisipatif juga mengafirmasi partisipasi membuka peluang bagi masyarakat untuk memengaruhi pengalokasian anggaran (misalnya, Ebdon dan Franklin, 2006; Zhang dan Yang, 2009). Pada saat bersamaan, studi Open Society Justice Initiative (OSJI) (dalam McGee dan Gaventa, 2010), mengemukakan kebebasan arus informasi (transparansi) memiliki kontribusi dalam kaitannya dengan responsivitas negara (pemerintah). Demikian pula, sejumlah studi tentang anggaran menjustifikasi partisipasi publik dan transparansi 
menjadi isu penting dalam proses pengambilan kebijakan anggaran terkait dengan penggunaan atau alokasi anggaran daerah (misalnya, Dwiyanto, dkk, 2003; Farhan dan Bush, 2010).

Selanjutnya, Bryer dan Cooper (2007) dalam studinya berargumen komitmen pemerintah secara berkesinambungan dibutuhkan dalam mendorong responsivitasnya. Mengikuti pendapat North, peran penting komitmen tidak hanya pada level institusi, tetapi tindakan aktor-aktor itu sendiri, seperti pemerintah dalam suatu lingkungan institusi (North, 1990 dalam Stevens dan Cooper, 2009:599). Artinya, komitmen pemerintah daerah sebagai aktor perumus kebijakan anggaran menjadi relevan mengingat APBD sebagai keluaran kebijakan yang merefleksikan bentuk komitmen pemerintah daerah dengan kesepakatan bersama DPRD. Terutama, pemerintah daerah memiliki peran yang cukup besar dalam penyusunan kebijakan anggaran, sehingga komitmen menjadi fundasi penting untuk mengartikulasikan kepentingan dan kebutuhan masyarakat dalam kebijakan anggaran.

Studi ini mendiskusikan responsivitas anggaran dalam hubungannya secara konseptual dengan partisipasi publik, transparansi anggaran dan komitmen perumus kebijakan anggaran (pemerintah daerah) di dalam konteks proses penyusunan APBD Kab. Sleman tahun 2013. Meski demikian, upaya tersebut bersifat penjajakan awal terhadap proposisi hipotesis yang dibangun dalam studi ini, sehingga diharapkan memiliki kontribusi terhadap kajian topik responsivitas. Hipotesis penelitian ini, yakni pertama (H1) partisipasi publik memiliki pengaruh positif terhadap responsivitas anggaran; kedua ( $\mathrm{H} 2)$ transparansi anggaran memiliki pengaruh positif terhadap responsivitas anggaran; ketiga $(\mathrm{H} 3)$ komitmen perumus kebijakan memiliki pengaruh positif terhadap responsivitas anggaran; dan keempat $(\mathrm{H} 4)$ partisipasi publik, transparansi anggaran dan komitmen perumus kebijakan secara bersama-sama berpengaruh positif terhadap responsivitas anggaran. Model penelitian digambarkan dengan sederhana seperti pada Gambar 1.

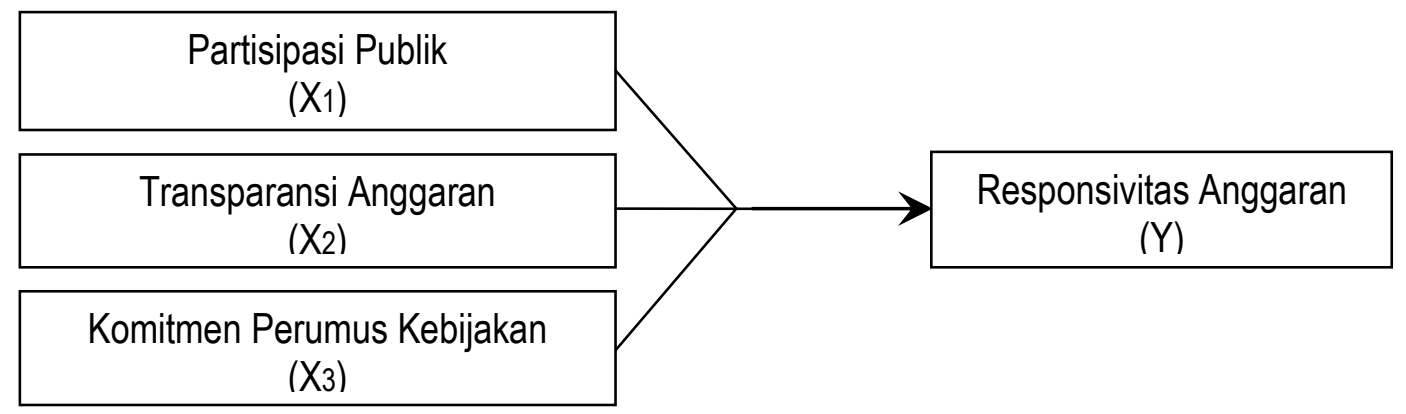

Gambar 1. Model penelitian

Penelitian ini difokuskan pada responsivitas anggaran dalam konteks proses penyusunan kebijakan anggaran daerah Kab. Sleman tahun 2013. Dengan asumsi bahwa responsivitas anggaran menunjuk pada daya tanggap atau keberpihakan pemerintah daerah terhadap kepentingan dan kebutuhan masyarakat dalam bentuk pengambilan kebijakan anggaran daerah, maka subjek penelitian ini adalah para pelaku atau pengambil kebijakan anggaran yang terdiri dari unsur pemerintah daerah diwakili oleh Satuan Kerja Perangkat Daerah (SKPD), dan DPRD sebagai unsur penyelenggaraan pemerintahan daerah. SKPD tersebut meliputi Badan Perencana Pembangunan Daerah/Bappeda, Dinas Pengelolaan Keuangan dan Aset Daerah/DPKAD, Dinas Pendidikan, dan Bagian Administrasi Pembangunan.

Data primer dalam penelitian ini diperoleh melalui survei dengan instrumen kuesioner, sedangkan data sekunder diperoleh dari studi literatur, dokumen anggaran tahun 2010-2013 dan 
dokumen lain yang terkait. Purposive sampling digunakan sebagai teknik dalam pengumpulan data, dengan pertimbangan subjek penelitian ini adalah para pelaku atau pengambil kebijakan anggaran daerah, serta meliputi unsur masyarakat sebagai kelompok sasaran sekaligus pemangku kepentingan di dalamnya. Untuk itu, sampel penelitian ini meliputi (1) para pegawai di empat SKPD yang memiliki jabatan struktural yang tugas dan fungsinya berkaitan langsung dengan perencanaan atau penyusunan APBD, khususnya di sektor pendidikan, (2) anggota DPRD Kab. Sleman periode 2010-2014, dan (3) unsur masyarakat meliputi warga dan tokoh masyarakat, LSM, Ormas, Organisasi Profesi dan organisasi lainnya, dengan kriteria pernah terlibat maupun memiliki perhatian terhadap penyusunan, pemantauan dan advokasi anggaran daerah.

Pengumpulan data dilakukan dengan menyerahkan kuesioner yang diantar langsung ke responden. Jumlah responden penelitian sebanyak 120 responden yang terdiri dari 40 orang pegawai di empat SKPD yang terlibat langsung dalam penyusunan APBD terutama pada sektor pendidikan, 20 orang anggota DPRD, dan 60 orang warga serta kelompok masyarakat di Kab. Sleman dengan kriteria yang telah ditetapkan.

Penelitian ini menetapkan partisipasi publik, transparansi anggaran dan komitmen perumus kebijakan (pemerintah daerah) sebagai variabel independen, dan responsivitas anggaran sebagai variabel dependen. Masing-masing variabel terdiri dari beberapa aspek dan dijabarkan menjadi butir pertanyaan yang mengacu pada teori yang terkait.

Partisipasi publik didefinisikan sebagai keterlibatan masyarakat dalam aktivitas penyusunan kebijakan anggaran daerah. Pengukuran variabel partisipasi publik ini mengacu pada aspek-aspek yang terkait seperti oleh Liao dan Zhang (2012), Farhan dan Robin (2010), dan Hardojo, dkk (2008). Daftar pertanyaan sebanyak 10 butir pertanyaan yang terdiri dari 3 aspek partisipasi, yaitu sarana menjaring partisipasi, pemanfaatan sarana partisipasi, dan pelibatan masyarakat dalam pengambilan kebijakan anggaran. Transparansi anggaran adalah keterbukaan dan ketersediaan informasi menyangkut proses penyusunan kebijakan anggaran daerah maupun dokumennya. Pengukuran transparansi mengacu pada pandangan seperti oleh Caamaño-Alegre (2011), Farhan dan Robin (2010), Hardojo, dkk (2008), Dwiyanto, dkk, (2003). Daftar pertanyaan transparansi anggaran sebanyak 12 butir pertanyaan yang terdiri dari 3 aspek, yaitu keterbukaan aktivitas penyusunan anggaran, ketersediaan dokumen anggaran dan akses masyarakat, serta kualitas informasi anggaran.

Komitmen perumus kebijakan didefinisikan sebagai kesanggupan pemerintah daerah untuk melaksanakan apa yang dinyatakan. Pengukuran komitmen mengacu pada pandangan Salancik (1977) dalam Stevens dan Cooper (2009), Robertson dan Tang, (1995). Komitmen tersebut dinilai dari karakteristik perilaku yang berupa atribusi tindakan (kebijakannya), yaitu ketegasan (explicitness), publisitas (publicity) atau berkaitan dengan tindakan yang dapat dinilai oleh masyarakat, dan kemauan/kehendak (volition). Ketiga aspek ini dijabarkan kedalam 9 butir pertanyaan untuk menilai komitmen pemerintah daerah berkaitan dengan visi dan misi, masalah dan prioritas pembangunan daerah terutama di bidang pendidikan yang diterjemahkan ke dalam kebijakan anggaran.

Selanjutnya, responsivitas anggaran daerah didefinisikan sebagai keberpihakan pemerintah daerah kepada masyarakat dalam wujud pengambilan kebijakan anggaran meliputi penyusunan program-program dan pengalokasiannya yang didasarkan pada aspirasi, kepentingan dan kebutuhan masyarakat. Pengukuran responsivitas anggaran mengacu pada penjelasan seperti oleh Hardojo, dkk (2008), Dwiyanto, dkk, (2003), dan Yang (2007). Daftar pertanyaan responsivitas anggaran sebanyak 6 butir pertanyaan teridiri dari 3 aspek, yaitu respon dan daya tanggap pemerintah daerah, 
penyusunan program/kegiatan prioritas pembangunan, dan alokasi dana APBD khususnya di bidang pendidikan.

Pengukuran masing-masing variabel menggunakan skala Likert dengan memberi skor pada pilihan jawaban dari satu sampai lima. Untuk variabel partisipasi publik, skor satu diartikan tidak pernah sama sekali, skor lima diartikan selalu. Sedangkan, untuk masing-masing variabel transparansi, komitmen perumus kebijakan dan responsivitas anggaran, skor satu diartikan sangat tidak setuju dan skor lima diartikan sangat setuju. Uji coba kuesioner dilakukan kepada sejumlah pegawai di lingkungan SKPD Kab. Sleman dan unsur masyarakat dengan melibatkan sebanyak 30 subjek penelitian.Untuk menguji hipotesis, metode analisis data yang digunakan adalah analisis regresi linear berganda.

\section{HASIL DAN PEMBAHASAN}

Dari 120 kuesioner yang diserahkan kepada responden ternyata hanya 110 kuesioner yang kembali, dan sisanya sebanyak 10 kuesioner tidak kembali. Tingkat respon pengembalian kuesioner tergolong cukup tinggi (91,67\%). Dari 110 kuesioner tersebut, hanya 108 kuesioner $(98,18 \%)$ yang dapat diolah datanya, sedangkan sisanya dua kuesioner tidak dapat diolah karena pengisiannya tidak lengkap. Adapun karakteristik responden secara umum adalah sebanyak $71,30 \%$ responden berjenis kelamin laki-laki, 53,70\% responden berusia 25-50 tahun, dan sebanyak 62,04\% responden pernah terlibat dalam penyusunan APBD selama kurun waktu lima tahun terakhir (2009-2013).

\section{Uji Validitas dan Reliabilitas}

Dari 37 butir pertanyaan kuesioner untuk mengukur keempat variabel penelitian, yaitu partisipasi publik, transparansi dan komitmen perumus kebijakan anggaran, serta responsivitas anggaran, seluruh butir pertanyaan dinyatakan telah valid. Untuk partisipasi publik, nilai koefisien berkisar antara 0,528 hingga 0,790, transparansi anggaran berkisar antara 0,402 hingga 0,809, komitmen perumus kebijakan berkisar antara 0,532 hingga 0,809, dan nilai koefisien untuk responsivitas anggaran berkisar antara 0,564 hingga 0,825. Sementara, untuk uji reliabilitas dilakukan dengan teknik Cronbach's Alpha. Apabila nilai Cronbach's Alpha lebih besar dari 0,70 berarti instrumen (kuesioner) telah reliabel (Nunnally, 1994 dalam Ghozali, 2011:48). Berdasarkan hasil uji reliabilitas, kuesioner telah reliabel (andal) dengan nilai Cronbach's Alpha untuk masingmasing variabel yang diteliti berada pada kisaran 0,894 - 0,908 (Tabel 1).

Tabel 1. Ringkasan Hasil Uji Reliabilitas

\begin{tabular}{lcc}
\hline \multicolumn{1}{c}{ Variabel } & Cronbach's Alpha & Keterangan \\
\hline Partisipasi Publik & 0,897 & Reliabel \\
Transparansi Anggaran & 0,894 & Reliabel \\
Komitmen Perumus Kebijakan & 0,901 & Reliabel \\
Responsivitas Anggaran & 0,908 & Reliabel \\
\hline
\end{tabular}

\section{Statistik Deskriptif}

Statistik deskriptif variabel-variabel yang diteliti dalam penelitian ini diringkas dalam Tabel 2. Nilai rata-rata (mean) yang tampak pada Tabel 2 menunjukkan tingkat jawaban responden untuk setiap variabel dalam penelitian ini adalah cukup tinggi.

Uji hipotesis dengan analisis regresi dapat dilakukan karena pengujian asumsi regresi telah memenuhi persyaratan. Untuk menguji keempat rumusan hipotesis, yaitu pengaruh partisipasi publik, 
transparansi dan komitmen perumus kebijakan anggaran, secara parsial dan simultan terhadap responsivitas anggaran dilakukan analisis regresi linear berganda dengan menggunakan program SPSS versi 19 seperti disajikan dalam Tabel 3.

Tabel 2. Ringkasan Statistik Deskriptif

\begin{tabular}{lccccc}
\hline \multicolumn{1}{c}{ Variabel } & N & $\begin{array}{c}\text { Nilai } \\
\text { Minimum }\end{array}$ & $\begin{array}{c}\text { Nilai } \\
\text { Maksimum }\end{array}$ & Mean & $\begin{array}{c}\text { Standar } \\
\text { Deviasi }\end{array}$ \\
\hline Partisipasi Publik & 108 & 19 & 50 & 35,70 & 7,116 \\
Transparansi Anggaran & 108 & 25 & 60 & 46,50 & 8,683 \\
Komitmen Perumus Kebijakan & 108 & 28 & 45 & 38,35 & 4,416 \\
Responsivitas Anggaran & 108 & 15 & 30 & 24,44 & 2,939 \\
\hline
\end{tabular}

Tabel 3. Rangkuman Hasil Analisis Regresi Berganda

\begin{tabular}{|c|c|c|c|c|c|c|}
\hline \multirow[b]{2}{*}{ Variabel } & \multirow{2}{*}{$\begin{array}{l}\text { Koefisien } \\
\text { regresi }(\beta)\end{array}$} & \multirow[b]{2}{*}{ Nilai t } & \multirow{2}{*}{$\begin{array}{l}\text { Nilai } p \\
\text { (Sig.) }\end{array}$} & \multicolumn{3}{|c|}{ Nilai Koefisien Parsial } \\
\hline & & & & $\mathrm{R}$ & $\mathrm{R}^{2}$ & $\begin{array}{c}\text { Adjusted } \\
\mathrm{R}^{2}\end{array}$ \\
\hline Konstan & 6,394 & 3,656 & 0,000 & - & - & - \\
\hline Partisipasi Publik & 0,065 & 2,045 & 0,043 & 0,447 & 0,200 & 0,192 \\
\hline Transparansi Anggaran & 0,074 & 2,542 & 0,012 & 0,563 & 0,317 & 0,311 \\
\hline $\begin{array}{l}\text { Komitmen Perumus } \\
\text { Kebijakan }\end{array}$ & 0,321 & 5,181 & 0,000 & 0,690 & 0,476 & 0,471 \\
\hline $\begin{array}{l}\mathrm{R}=0,725 ; \quad \mathrm{R}^{2}=0,525 ; \\
\mathrm{F}=38,367 ; \text { Sig. } \mathrm{F}=0,0\end{array}$ & $d R^{2}=0,512$ & & & & & \\
\hline
\end{tabular}

Berdasarkan Tabel 3 variabel independen yang dimasukkan dalam model regresi (partisipasi publik, transparansi anggaran dan komitmen perumus kebijakan) secara parsial dan simultan memiliki pengaruh positif dan signifikan terhadap responsivitas anggaran. Sementara, besaran pengaruh tersebut dapat ditunjukkan oleh koefisien determinasi pada perubahan nilai $R$ square (Adjusted $\mathrm{R}^{2}$ ) (Ghozali, 2011:97). Adapun persamaan regresi yang diperoleh dari hasil pengujian tersebut adalah sebagai berikut.

$$
Y=6,394+0,065 X 1+0,074 X 2+0,321 X 3
$$

\section{Partisipasi Publik dan Responsivitas Anggaran}

Hasil analisis regresi pada Tabel 3 menunjukkan bahwa partisipasi publik (masyarakat) memiliki pengaruh positif dan signifikan terhadap responsivitas anggaran dengan tingkat keyakinan $95 \%$ (a sebesar 0,05 ). Hal ini ditunjukkan dengan nilai koefisien regresi yang positif dan signifikan (b $=0,065 ; t=2,045 ; p<0,05$ ). Koefisien determinasi pada perubahan nilai $R$ square (adjusted $R^{2}$ ) sebesar 0,192 diartikan bahwa variasi dalam variabel responsivitas anggaran sebesar 19,2\% dijelaskan oleh variabel partisipasi publik, sedangkan sisanya sebesar $80,8 \%$ harus dijelaskan oleh faktor-faktor lain yang tidak diteliti. Dengan demikian, hipotesis yang diajukan (H1) tidak dapat ditolak yang menyatakan partisipasi publik memiliki pengaruh positif terhadap responsivitas anggaran. Nilai koefisien pada persamaan regresi sebesar 0,065 diartikan bahwa apabila partisipasi 
publik dinaikkan sebesar satu satuan maka akan diikuti oleh kenaikan responsivitas anggaran sebesar 0,065 dengan asumsi variabel bebas yang lain konstan.

Salah satu muara partisipasi dalam penganggaran adalah terwujudnya kebijakan anggaran yang responsif melalui pengaruh masyarakat di dalamnya (Ebdon dan Franklin, 2006; Zhang dan Yang, 2009; Liao dan Zhang, 2012). Hasil penelitian ini relevan apabila dikaitkan dengan studi Yang dan Callahan (2007), bahwa upaya pelibatan masyarakat yang diprakarsasi oleh manajer kota sebagai proksi pemerintah lokal, salah satunya mencerminkan responsivitas birokrasi terhadap kelompok pemangku kepentingan dalam masyarakat. Demikian halnya, studi Korolev (2012) menyimpulkan partisipasi masyarakat berpengaruh positif dan signifikan terhadap responsivitas pemerintah untuk kebutuhan masyarakat.

Berdasarkan hasil penelitian ini, partisipasi publik dalam proses penyusunan kebijakan anggaran daerah/APBD sebesar 19,2\% pengaruhnya terhadap responsivitas anggaran. Pengaruh partisipasi yang dapat dikatakan tergolong rendah tersebut tidak terlepas dari mekanisme dan sarana yang tersedia. Kurniadi, dkk, (2009) mengemukakan partisipasi (pelibatan) masyarakat dapat dilihat dari akses terhadap ruang partisipasi dan hak suara bagi masyarakat. Dalam proses penyusunan kebijakan APBD, partisipasi berlangsung melalui skema musyawarah perencanaan pembangunan (Musrenbang) mulai dari level desa, kecamatan hingga pada level kabupaten. Hal ini merefleksikan masyarakat memiliki ruang untuk terlibat dalam pengambilan keputusan program-program prioritas pembangunan. Selain itu, masyarakat diberikan hak suara berupa masukan, kritikan maupun komentar terhadap rencana kebijakan APBD melalui forum dengar pendapat yang dilaksanakan oleh DPRD sebelum memasuki proses pembahasan dan pengesahan APBD.

Pada konteks tersebut, pengaruh partisipasi masyarakat dalam penyusunan kebijakan anggaran daerah muncul pada tingkatan partisipasi yang sifatnya informatif dan konsultatif sebagaimana halnya tipologi partisipasi yang dikemukakan oleh Arnstein (1969), atau disebut partisipasi parsial dengan tingkat pengaruh yang sedikit (Moynihan, 2003 dalam Purwanto, 2008:188). Dengan kata lain, kesempatan masyarakat untuk terlibat dan memberi hak suara dalam proses penyusunan APBD dalam sesi yang terbatas termanifestasi pada konsultasi dan dengar pendapat. Sementara, pada proses pembahasan anggaran menyangkut skala prioritas daerah, masyarakat belum memiliki ruang untuk terlibat di dalamnya. Artinya, proses penyusunan kebijakan APBD nyaris didominasi oleh aktor perumus kebijakan anggaran dari lembaga eksekutif dan legislatif. Hal ini potensial melahirkan persoalan substantif menyangkut akses masyarakat dalam mengawal aspirasi dan kebutuhan yang disampaikan kepada pihak eksekutif maupun legislatif. Temuan lapangan menunjukkan bahwa usulan prioritas kebutuhan masyarakat di bidang pendidikan tidak sepenuhnya diakomodir dalam APBD tahun 2013, seperti halnya pengadaan Alat Permainan Edukatif (APE) pendidikan anak usia dini dan fasilitas taman pintar dan desa layak anak di Kecamatan Sleman Kab. Sleman. Hal ini relevan sebagaimana Dwiyanto, dkk (2003) mengemukakan bahwa program-program pembangunan yang digulirkan oleh pemerintah daerah sering tidak mencerminkan aspirasi dan kebutuhan masyarakat yang diputuskan secara partisipatif dari tingkat bawah.

Berdasarkan uraian tersebut, adanya pengaruh partisipasi publik terhadap responsivitas anggaran, merefleksikan bahwa partisipasi menjadi agenda utama bagi para pemegang otoritas kebijakan dalam arena pengambilan kebijakan anggaran daerah. Sebagaimana halnya Marlowe dan Portilo (2006) menegasi para manajer sebagai proksi pemerintah lokal memandang input masyarakat cenderung bermanfaat untuk lebih memfokuskan kebijakan terhadap kepentingan masyarakat luas ketimbang kepentingan sempit. Dengan demikian, partisipasi dapat menjadi "keran" bagi masyarakat 
dalam menggiring alokasi sumber daya (anggaran) yang responsif terhadap kepentingan publik (Justice dan Dülger, 2009). Dengan demikian, partisipasi masyarakat yang aktif menjadi tantangan kedepannya dalam proses kebijakan anggaran.

\section{Transparansi Anggaran dan Responsivitas Anggaran}

Hasil analisis regresi (Tabel 3) mengkonfirmasi bahwa transparansi anggaran memiliki pengaruh positif dan signifikan terhadap responsivitas anggaran dengan tingkat keyakinan 95\% (a sebesar 0,05$)$ yang ditunjukkan dengan nilai koefisien regresi positif dan signfikan $(b=0,074 ; t=$ $2,542 ; p<0,05)$. Pengaruh transparansi anggaran tersebut berdasarkan perubahan nilai $R$ square (Adjusted $\mathrm{R}^{2}$ ) adalah sebesar 0,311 atau sebesar 31,1\% pengaruhnya terhadap responsivitas anggaran, sedangkan selebihnya $68,9 \%$ dijelaskan oleh faktor-faktor lainnya yang tidak diteliti. Hasil ini mengkonfirmasi bahwa hipotesis $(\mathrm{H} 2)$ tidak dapat ditolak, sebagaimana dikemukakan terdahulu. Adapun nilai koefisien regresi 0,074 menunjukkan apabila transparansi anggaran dinaikkan sebesar satu satuan maka akan diikuti oleh kenaikan responsivitas anggaran sebesar 0,074.

Secara teoritis, transparansi kental dengan kebebasan arus informasi, dan oleh karenanya, transparansi memiliki peran penting dalam proses penyusunan kebijakan anggaran daerah/APBD mengingat anggaran sebagai fundasi terlaksananya kebijakan dan program-progam pembangunan untuk kepentingan public. Hasil penelitian ini relevan bila ditautkan dengan studi Open Society Justice Initiative (OSJI) di 14 negara (dikutip oleh McGee dan Gaventa, 2010:30). Demikian halnya, PBB (2007) menjelaskan bahwa transparansi memiliki peran dalam hal pemerintahan yang responsif kepada publik. Untuk itu, transparansi dalam proses penyusunan kebijakan APBD sebagai faktor penting dalam menjelaskan responsivitas anggaran. Dengan kalimat lain, transparansi anggaran menjadi fundasi dalam proses kebijakan anggaran yang responsif, terutama menyangkut aksesibilitas dan akurasi informasi (Kurniadi, dkk, 2009).

Berdasarkan hasil penelitian ini, adanya pengaruh transparansi anggaran terhadap responsivitas anggaran tidak lepas dari mekanisme yang tersedia. Keterbukaan informasi menyangkut proses penyusunan kebijakan APBD dan dokumennya, dilakukan oleh pemerintah daerah diantaranya melalui website (situs) daerah, media massa, maupun melalui forum dengar pendapat yang diselenggarakan oleh DPRD. Artinya, proses penyusunan APBD Kab. Sleman telah dikemas dalam spirit transparansi, akan tetapi belum sepenuhnya dilakukan secara transparan kepada publik. Masyarakat tampak nyaris sulit untuk mengetahui rincian alokasi anggaran dan skala prioritas program-program pembangunan daerah dan pembiayaannya. Informasi mengenai APBD yang disajikan melalui website daerah masih berupa ringkasan APBD meliputi jumlah total anggaran pendapatan dan belanja daerah, serta pembiayaan di dalamnya. Padahal, transparansi memberi kemudahan bagi masyarakat untuk mengakses berbagai informasi tentang anggaran. Lebih jauh, masyarakat dapat menilai orientasi kebijakan anggaran yang dihasilkan, apakah berpihak pada kepentingan dan kebutuhan masyarakat, atau berpihak pada segelintir elit daerah dan kelompoknya (Dwiyanto, dkk, 2003). Dengan kalimat lain, pengambilan kebijakan anggaran yang mendasari pada kepentingan publik potensial diwujudkan jika dibingkai dengan transparansi secara memadai.

Berdasarkan uraian tersebut, transparansi dalam proses penyusunan kebijakan anggaran merupakan agenda penting ke depannya, baik sebagai praktik ataupun acuan bagi pemerintah daerah dan institusinya, terutama menyangkut keterbukaan dan jaminan akses informasi bagi masyarakat. Apalagi, transparansi sebagai bagian dari prinsip tata kelola yang baik dalam proses penyelenggaraan pemerintahan secara keseluruhan. Lahirnya UU No. 14 tahun 2008 tentang 
Keterbukaan Informasi Publik (KIP) setidaknya menegasi hal itu. Dengan demikian, keterbukaan informasi anggaran tanpa adanya distorsi informasi adalah menjadi tantangan untuk kedepannya.

\section{Komitmen Perumus Kebijakan dan Responsivitas Anggaran}

Berdasarkan hasil analisis regresi (Tabel 3), komitmen perumus kebijakan anggaran (pemerintah daerah) memiliki pengaruh positif dan signifikan terhadap responsivitas anggaran dengan tingkat keyakinan 99\% (a sebesar 0,01) yang ditunjukkan dengan nilai koefisien regresi positif dan signifikan ( $b=0,321 ; t=5,181 ; p<0,01$ ). Perubahan nilai $R$ square (Adjusted $\mathrm{R}^{2}$ ) sebesar 0,471 diartikan bahwa sebesar 47,1\% pengaruh komitmen terhadap responsivitas anggaran, sedangkan sisanya sebesar $52,9 \%$ harus dijelaskan oleh faktor-faktor lain yang tidak diteliti. Dengan demikian, hipotesis $(\mathrm{H} 3)$ tidak dapat ditolak, atau komitmen perumus kebijakan berpengaruh positif terhadap responsivitas anggaran. Nilai koefisien regresi sebesar 0,321 diartikan jika komitmen dinaikkan sebesar satu satuan maka akan diikuti oleh kenaikan responsivitas anggaran sebesar 0,321 .

Pada dasarnya, tujuan kebijakan anggaran adalah terpenuhinya kebutuhan dasar masyarakat seperti halnya pelayanan publik. Blunt (1995) berargumen bahwa pemerintah berperan cukup besar dalam penyediaan pelayanan sosial dasar, seperti layanan pendidikan, kesehatan dan infrastruktur. Untuk itu, terwujudnya kebijakan anggaran yang berpihak pada kepentingan dan kebutuhan masyarakat sangat mungkin dilakukan jika diimbangi dengan komitmen para perumus kebijakan anggaran. Hasil penelitian ini relevan jika dikaitkan dengan pandangan Bryer dan Cooper (2007), dan Hardojo, dkk (2008) seperti dikemukakan terdahulu.

Pengaruh komitmen perumus kebijakan terhadap responsivitas anggaran dalam penelitian ini sebesar 47,1\%. Hal ini terkait dengan upaya pemerintah daerah dalam mewujudkan visi dan misi, serta prioritas pembangunan yang diterjemahkan ke dalam kebijakan APBD. Hal ini terefleksikan dari orientasi APBD terhadap program-program pembangunan dan layanan publik seperti di bidang pendidikan sesuai visi dan misi daerah. Jika melirik pada tinjauan alokasi pendidikan misalnya, pemerintah daerah (Kab. Sleman) telah mengalokasikan anggaran daerah untuk pendidikan lebih dari $20 \%$ sesuai amanat konstitusi, seperti dikemukakan pada bagian terdahulu. Pada saat yang sama, komitmen pemerintah daerah tercermin melalui penerapan kebijakan Pagu Indikatif usulan Kecamatan (PIK) sejak tahun 2012 untuk perencanaan pembangunan tahun 2013. PIK tahun 2013 sebesar $15 \%$ dari dana APBD tahun berjalan pada pos Belanja Langsung, dikurangi kewajiban yang harus dilaksanakan (belanja wajib), dan dikurangi dengan prediksi defisit anggaran.

Gagasan PIK tersebut dimaknai sebagai upaya untuk mengakomodir usulan-usulan prioritas masyarakat dalam APBD tahun 2013. Tujuannya, diharapkan pembangunan daerah yang lebih adil dan merata selaras dengan visi dan misi daerah dapat diwujudkan.

Berdasarkan uraian tersebut, komitmen sebagai isyarat penting dalam proses pengambilan kebijakan anggaran yang responsif. Artinya, komitmen pemerintah daerah dalam hal kebijakan anggaran yang berlandaskan pada visi dan misi daerah, serta prioritas pembangunan daerah bergantung pada niat dari pemerintah daerah. Sebagaimana halnya Meier (2000) dalam Yang dan Pandey (2007:220) menyebut bahwa dukungan pejabat terpilih (pemerintah) dapat menjelaskan tingkat kinerja institusi publik. Selanjutnya, Yang dan Pandey (2007) menyebut tingginya tingkat dukungan pejabat terpilih berhubungan positif dengan tingginya tingkat responsivitas institusi publik. Dengan demikian, hasil ini mengarfimasi komitmen memiliki peran penting yang tidak bisa diabaikan bagi pemerintah dan institusinya (Robertson dan Tang, 1995; Salancik, 1977 dalam Stevens dan Cooper, 2009 dan Robertson dan Tang, 1995). Dengan demikian, semakin kebijakan anggaran 
ditandai dengan atribusi tindakan (kebijakannya) seperti ketegasan/eksplisit, publisitas atau tindakan yang dapat dinilai oleh publik, dan kemauan/kehendak didasarkan pada kepentingan publik, semakin berkomitmen pemerintah daerah, dan semakin mampu dalam membangun komitmennya secara kredibel.

\section{Partisipasi Publik, Transparansi Anggaran, Komitmen Perumus Kebijakan dan Responsivitas Anggaran}

Hasil penelitian ini menunjukkan bahwa partisipasi publik, transparansi anggaran, dan komitmen perumus kebijakan, secara bersama-sama memiliki pengaruh positif dan signifikan terhadap responsivitas anggaran dengan tingkat keyakinan 99\% (a sebesar 0,01) (Tabel 3). Hal ini ditunjukkan dengan nilai koefisien regresi yang positif dan signifikan $(b=6,394 ; F=38,367 ; p<$ 0,01). Nilai konstanta sebesar 6,394 menunjukkan responsivitas anggaran telah ada sebesar 6,394, jika partisipasi publik, transparansi anggaran dan komitmen perumus kebijakan dianggap konstan. Adapun pengaruh ketiga variabel independen tersebut secara bersama-sama terhadap variabel responsivitas anggaran ditunjukkan dengan perubahan nilai $\mathrm{R}$ square (Adjusted $\mathrm{R}^{2}$ ) sebesar 0,512 atau dengan prosentase sebesar $51,2 \%$, sedangkan selebihnya $48,8 \%$ dijelaskan oleh faktor lainnya di luar dari model penelitian ini. Dengan demikian, hipotesis $(\mathrm{H} 4)$ yang diajukan dalam penelitian ini tidak dapat ditolak, sebagaimana dikemukakan terdahulu.

Sebagai instrumen kebijakan, responsivitas anggaran sebagai sebuah keharusan untuk terus-menerus diupayakan. Untuk itu, kebijakan anggaran yang responsif memerlukan komitmen pemerintah daerah untuk mengelola anggaran daerah berorientasi pada kepentingan publik. Namun demikian, hal ini akan sulit dicapai jika tanpa diiringi dengan tata kelola anggaran yang baik. Dalam konteks itu lah, prinsip partisipasi dan transparansi menjadi elemen penting lainnya dalam menggiring kebijakan anggaran yang lebih efisien, efektif, dan responsif.

Berdasarkan hasil penelitian ini, partisipasi publik, transparansi anggaran dan komitmen perumus kebijakan anggaran secara bersama-sama berpengaruh terhadap responsivitas anggaran. Secara parsial, komitmen perumus kebijakan mempunyai pengaruh yang terbesar dengan prosentase $47,1 \%$, disusul dengan transparansi anggaran sebesar $31,1 \%$, dan terakhir adalah partisipasi publik dengan pengaruhnya sebesar 19,2\%. Hal ini dapat dimaknai bahwa komitmen merupakan prioritas utama dalam proses kebijakan anggaran yang responsif, berpangkal pada kepentingan publik. Namun demikian, partisipasi publik dan transparansi anggaran sebagai faktor penting lainnya. Melalui partisipasi publik dan transparansi, diharapkan setiap kebijakan pemerintah akan responsif terhadap publik (PBB, 2007). Dalam praksisnya, partisipasi masyarakat yang aktif akan sulit muncul sepanjang masyarakat tidak memperoleh kemudahan untuk mengakses berbagai informasi, kecuali hal itu didukung oleh transparansi secara memadai (Justice dan Dülger, 2009). Pada saat yang sama, upaya tersebut mengirim sinyal terhadap dukungan komitmen pemerintah daerah (King, Feltey dan Susel, 1998). Hal ini juga relevan dengan beberapa studi empiris tentang anggaran lokal yang menekankan signifikansi peran manajer sebagai proksi pemerintah lokal dalam formulasi kebijakan anggaran (Marlowe \& Portillo, 2006; Zhang dan Yang, 2009; Liao dan Zhang, 2012).

\section{PENUTUP}

Sebagai sebuah penjajakan awal terhadap proposisi hipotesis yang dibangun dalam studi ini, hasil penelitian ini menunjukkan bukti empiris bahwa partisipasi publik, transparansi dan komitmen perumus kebijakan secara parsial dan simultan memiliki pengaruh positif dan signifkan terhadap 
responsivitas anggaran. Dari hasil pengujian statistik, pengaruh partisipasi publik, transparansi anggaran dan komitmen perumus kebijakan secara simultan terhadap responsivitas anggaran diperoleh sebesar $51,2 \%$. Secara parsial, pengaruh komitmen perumus kebijakan sebesar $47,1 \%$, transparansi anggaran sebesar $31,1 \%$, dan pengaruh partisipasi publik sebesar $19,2 \%$.

Dengan peran pemerintah daerah yang cukup besar dalam pengambilan kebijakan anggaran daerah, komitmen tampak sebagai preposisi dalam proses pengambilan kebijakan anggaran yang responsif. Artinya, upaya mewujudkan responsivitas anggaran tidak lepas dari peran pemerintah daerah dalam membangun komitmennya. Hasil analisis regresi secara parsial setidaknya menjustifikasi hal itu, dimana komitmen perumus kebijakan anggaran memiliki pengaruh lebih besar terhadap responsivitas anggaran jika ditautkan dengan pengaruh transparansi anggaran dan partisipasi publik. Namun demikian, transparansi anggaran dan partisipasi publik tidak bisa ditanggalkan ditengah arus reformasi anggaran daerah yang merupakan fundasi dalam memastikan kebijakan anggaran responsif terhadap kepentingan masyarakat luas. Dengan kata lain, responsivitas anggaran potensial untuk diwujudkan manakala proses penyusunan kebijakan anggaran daerah dilakukan dengan melibatkan masyarakat dan membuka akses seluas-luasnya kepada mereka. Dengan demikian, partisipasi publik, transparansi anggaran dan komitmen perumus kebijakan dapat menjelaskan responsivitas anggaran dalam konteks proses penyusunan kebijakan APBD, sehingga dapat dijadikan prioritas bagi pemerintah Kab. Sleman maupun pemerintah daerah lainnya.

Hasil penelitian ini mengimplikasikan pentingnya partisipasi publik, transparansi anggaran dan komitmen perumus kebijakan memiliki peran penting dalam rangka pemanfaatan keterbatasan anggaran daerah ke dalam konstruksi kebijakan anggaran yang mengedepankan nilai-nilai efisiensi, efektivitas dan responsif terhadap kepentingan masyarakat. Sekecil apapun pengaruh faktor-faktor tersebut terhadap responsivitas anggaran adalah tetap berada pada tataran utama bagi para pengambil kebijakan dan pemangku kepentingan terkait dalam proses pengambilan kebijakan anggaran daerah. Implikasi praktisnya, partisipasi publik, transparansi anggaran dan komitmen perumus kebijakan perlu ditinjau secara proporsional dan dipromosikan secara berkesinambungan untuk meningkatkan responsivitas yang lebih baik terhadap kepentingan masyarakat luas.

\section{REFERENSI}

Arnstein, S. R. (1969). A ladder of citizen participation. American Institution of Planning Journal, vol. 35(4), 216-224.

Bryer, T. A., \& Cooper, T. L. (2007). Challenges in enhancing responsiveness in neighborhood governance. Public performance \& management review, vol. 31(2), 191-214.

Caamaño-Alegre, J., Lago-Peñas, S., Reyes-Santias, F., \& Santiago-Boubeta, A. (2011). Budget transparency in local governments: an empirical analysis. International studies program working paper 11-02. Andrew young school of policy studies, Georgia State University. Diakses 30 September 2013 dari http://papers.ssrn.com/sol3/papers.cfm?abstract_id=1768091

Dwiyanto, A., dkk. (2003). Reformasi tata pemerintahan dan otonomi daerah. Yogyakarta: Pusat Studi Kependudukan dan Kebijakan Universitas Gadjah Mada.

Ebdon, C., \& Franklin, A., L. (2006). Citizen participation in budgeting theory. Public administration review, vol. 66(3), 437-447. 
Farhan, Y., \& Bush, R. (2010). Kinerja pengelolaan anggaran daerah 2009: Study di 41 kabupaten/kota di Indonesia, Jakarta: Seknas FITRA bekerjasama dengan The Asia Foundation, dan Departement for International Development.

Ghozali, H. I. (2011). Aplikasi analisis multivariat dengan program IBM SPSS 19. Semarang: Badan Penerbit Universitas Diponegoro.

Hanida, R. P. (2010). Dinamika penyusunan anggaran daerah: Studi tentang proses penetapan program dan alokasi anggaran belanja daerah di kabupaten Sleman, Tesis yang tidak dipublikasikan, Program Pascasarjana IImu Administrasi Negara, UGM, Yogyakarta.

Hardojo, A. P., dkk. (2008). Mendahulukan miskin: Buku sumber bagi anggaran pro rakyat (Waidl, A., Sudjito, A., \& Bahagijo, S. [Eds.]). Yogyakarta: LKS

Justice, J. B., \& Dülger, C. (2009). Fiscal transparency and authentic citizen participation in public budgeting: The role of third-party intermediation. Journal od public budgeting, accounting \& financial management, vol. 21(2), 254-288.

King, C. S., Feltey, K. M., \& Susel, B. O'Neill (1998). The question of participation: Toward authentic public participation in public administration. Public administration review, vol. 58(4), 317-326. Diakses 22 Maret 2013 dari http://www.jstor.org/stable/977561.

Korolev, A. (2012). Regime responsiveness to basic needs: A dimensional approach. Disertasi, School of government and public administration, The Chinese University of Hong Kong. Diakses 05 Agustus 2013, dari ProQuest ILC Database.

Kurniadi, B. D., dkk. (2009). Menuju bekerjanya tata pemerintahan lokal yang baik: Partisipasi, transparansi, dan akuntabilitas. Monograph on politics \& government, vol. 3(I), pp. 1-86.

Liao, Y., \& Zhang, Y. (2012). Citizen participation in local budgeting: Mechanisms, political support, and city manager's moderating role. International review of public administration, vol. 17(2), 19-38.

Mardiasmo. (2004). Otonomi dan manajemen keuangan daerah. (2th ed.) Yogyakarta: Andi.

Marlowe, J., \& Portillo, S. (2006). Citizen Engagement in Local Budgeting: Does Diversity Pay Dividends? Public Performance \& Management Review, Vol. 30 (2), 179-202.

McGee, R., \& Gaventa, J. (2010). Synthesis report: review of impact and effectiveness of transparency and accountability initiatives (Transparency and accountability initiatives). London: Open Society Foundation, Cambridge House.

PBB (United Nations). (2007). Towards participatory and transparent governance: Reinventing government (Publication based on 6th global forum on reinventing government: Towards participatory and transparent governance 26-27 May 2005, Seoul, Republic of Korea), Newyork: Department of economic and social affairs, division for public administration and development management.

Purwanto, E., A. (2008). Pelayanan publik partisipatif. Dalam Dwiyanto, A. (Ed), 2008, Mewujudkan good governance melalui pelayanan publik, Yogyakarta: Gadjah Mada University Press.

Robertson, P. J., \& Tang, Shui-Yan. (1995). The role of commitment in collective action: Comparing the organizational behavior and rational choice perspectives. Public administration review, vol. 55(1), 67-80.

Stevens, C. E., \& Cooper, J., T. (2009). A Behavioral Theory of Governments' Ability to Make Credible Commitments to Firms: The case of the East Asian paradox. Asia Pac J Manag, Vol. 27, 587-610.

Wildavsky, A. (1961). Political implications of budgetary reform. Public administration review, vol. 21(4), 183-190. 
Yang, K., \& Pandey, S., K. (2007). Public responsiveness of government organizations: Testing a preliminary model. Public performance \& management review, vol. 31(2), 215-240.

Yang, K. (2007). Responsiveness in network governance: Revisiting a fundamental concept: Symposium introduction. Public performance \& management review, vol. 31(2), 131-143.

Yang, K., \& Callahan, K. (2007). Citizen involvement efforts and bureaucratic responsiveness: Participatory values, stakeholder pressures, and administrative practicality. Public administration review, vol. 67 (2), 249-264.

Zhang, Y., \& Yang, K. (2009). Citizen participation in the budget process: The effect of city managers, journal of budgeting, accounting \& financial management, vol. 21(2), 289-317. 